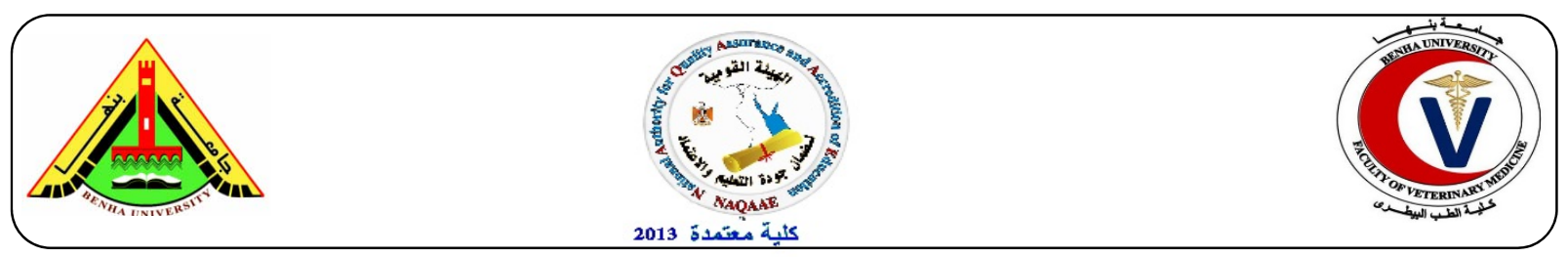

\title{
Comparative studies of Listeria monocytogenes survival in bifidus and traditional yoghurt during production and storage
}

\author{
Huda E. Othman'; Hamdi M. Abdelsamei²; Adham M. Abdou. ${ }^{2}$; Ekbal M. A. Ibrahim ${ }^{2}$ and \\ Azza, H. Elbaba ${ }^{1}$ \\ ${ }^{1}$ Food Hygiene Department, Animal Health Research Institute, ARC, Dokki, Giza, Egypt. \\ ${ }^{2}$ Milk Hygiene, Department of Food Control, Fac. of Vet. Med., Benha Univ., Egypt
}

\section{A B S T R A C T}

Antagonistic activity of Bifidobacterium bifidum against Listeria monocytogenes during the production and storage of Traditional yoghurt (TY) (Streptococcus thermophiles+ Lactobacillus bulgaricus) and Bifidus yoghurt (BY) samples (Streptococcus thermophiles+ Lactobacillus bulgaricus + Bifidobacterium bifidum). Traditional \& Bifidus yoghurt samples were inoculated with $10^{6} \mathrm{cfu} / \mathrm{g} \mathrm{L}$. monocytogenes and stored for 21 days at $4 \pm 1^{\circ} \mathrm{C}$. Samples were taken at zero time (fresh samples) then after 3, 5, 7, 10, 14 and 21 days of storage for titratable acidity measurement and bacterial count of the culture starters and $L$. monocytogenes counts. The results revealed that the titratable acidity of TY \& BY was increased during the 21 days of storage, while the population of L. monocytogenes became non-detectable level in $10^{\text {th }}$ days of storage in BY and still detected in TY till the day 14th of storage and became $2.20 \pm 0.31 \log _{10} \mathrm{cfu} / \mathrm{g}$. The count of all starter cultures (S. thermophiles + Lb. bulgaricus + B. bifidum) in both yoghurts increased during the fermentation and cold storage and remained stable with values $>6 \log _{10} \mathrm{cfu} / \mathrm{g}$ throughout the storage period at $4 \pm 1{ }^{\circ} \mathrm{C}$.

Keywords: probiotics, Bifidobacteria, L. monocytogenes, yoghurt, bifidus yoghurt.

(http://www.bvmj.bu.edu.eg)

(BVMJ-32(1): 121-126, 2017)

\section{1- INTRODUCTION}

During the last century, many reports were published, with variable results, regarding the benefits to health of consuming yoghurt. More recent studies focused on varies health benefits of the consumption of fermented milks with probiotic microorganisms (Kehagias et al., 2006; Ouwehand et al., 2002). The probiotics to be incorporated into milk or any other food must fulfill several criteria related to safety, health benefits, and processing parameters (Mattila-Sandholm et al., 2002). "Probiotics" are defined as" live microorganisms which when administered in adequate amounts (between $10^{6}-10^{7} \mathrm{cfu} / \mathrm{g}$ ) confer a health benefit on the host" (FAO/WHO, 2010). Therefore, viability and activity of the probiotic bacteria in yoghurt are of important consideration. Among the most often used, probiotic bacteria are species of the genus Bifidobacterium (Kehagias et al., 2006). Bifidobacteria constitute a major part of human intestinal microflora and play an important role in maintaining good health. The potential health benefits ascribed to bifidobacteria include inhibition of bacterial pathogens, reduction of serum cholesterol levels and colon cancer risks, stimulation of immune response, improvement of lactose tolerance, calcium absorption and vitamin synthesis. In addition to assistance of digestion, prevention of radiotherapy associated diarrhea, and control of intestinal gram-negative bacteria (Palacios et al., 2008; Wu et al., 2011). At present, bifidobacteria are increasingly in corporate into fermented dairy products. Bifidobacteria grow slowly in milk and the usual practice is to add yoghurt starter bacteria to enhance the fermentation process for making probiotic yoghurt. Several factors have been claimed to affect the viability of probiotics in yoghurt, including acidity, hydrogen peroxide, oxygen content, concentration of lactic acid and acetic acids, temperature of storage etc., during manufacture and storage of yoghurt (Kehagias et al., 2006). L. monocytogenes is Gram-positive foodborne pathogen, can cause illnesses extending from those with mild flu-like symptoms or gastroenteritis to more serious, potentially fatal conditions such as bacteremia and meningitis and in pregnancy can cause preterm delivery, fetal loss, neonatal infection, or infant death (Liu, 2006; McLauchlin et al., 2004). 
Between 1998 and 2008 in the USA, at least $25 \%$ of reported outbreaks of listeriosis were of dairy origin (Allerberger and Wagner, 2010).

This study is aimed to compare and evaluate the effect of bifidus and traditional yoghurt samples on survival of $L$. monocytogenes during production and during storage at $4 \pm 1^{\circ} \mathrm{C}$.

\section{2- MATERIALS AND METHODS}

\subsection{Yoghurt cultures}

Yoghurt cultures (were obtained from Chr. Hansen Lab., Copenhagen, Denmark). Traditional yoghurt starter culture (FD-DVS, YC-X11) contains Streptococcus thermophiles \& Lactobacillus delbrueckiisub spp. bulgaricus (1:1). Bifidus yoghurt starter culture contains Bifidobacterium bifidum Bb-12+ Streptococcus thermophiles+ Lactobacillus bulgaricus. All Starter cultures were prepared according to Hull and Robert (1984).

\section{2-2. L. monocytogenes}

L. monocytogenes NCTC 13372/ ATCC® 7644 was obtained from TCS Bioscience Ltd, United Kingdom and activated at Food Hygiene department- Animal Health Research InstituteDokki, Giza, Egypt. It was prepared according to Bachrouri et al. (2002).

2.3. Preparation of Traditional \& Bifidus yoghurt samples: according to Nighswonger et al. (1996).

\subsection{Chemical examination:}

2.4.1. Determination of titratable acidity: according to A.O.A.C. (2000).

\subsection{Microbiological examination:}

Yoghurt samples were taken at Zero time, 3, 5, 7, 10,14 and 21 days of cold storage $\left(4 \pm 1^{\circ} \mathrm{C}\right)$, thoroughly mixed aseptically immediately after opening of yoghurt cup, and from each prepared samples, 10 folds' serial dilutions were prepared according to APHA (2001) for the count of the following: $S$. thermophiles, $L b$. bulgaricus according to Kailasapathy et al. (2008) and B. bifidum according to Tharmaraj and Shah (2003). L. monocytogenes counts: according to A.P.H.A. (American Public Health Association) (2001).

2.6- Statistical analysis: Data were analyzed by using SPSS (2000)

\section{3- RESULTS}

The research was carried out to compare and evaluate the effect of traditional and bifidus yoghurt samples on survival of $L$. monocytogenes during production and storage at $4 \pm 1{ }^{\circ} \mathrm{C}$ and analyzed for T.A $\%$ and total counts of starter cultures and L. monocytogenes. The titratable acidity of both TY \& BY was increased and reached $0.69,0.71,0.78,0.80$ and 1.25 then spoiled by visualized mould growth in TY, while in BY reached $0.67,0.69,0.75,0.78,0.82,0.93$ and 1.17 at zero time, 3, 5, 7, 10, 14, and 21 days of storage, respectively (Table 1). The viability of the inoculated $L$. monocytogenes reached 7.00, 6.20, $5.80,5.00,3.13$ and $2.20 \log _{10} \mathrm{cfu} / \mathrm{g}$ in TY, while in $\mathrm{BY}$ reached $6.60,5.40,3.33$ and 1.47 at zero time, 3,5 and 7 days of storage, respectively and became non-detectable level in $10^{\text {th }}$ days of storage (Table 2). The changes in the viable counts of $S$. thermophilus, Lb. bulgaricus and B. bifidum in Bifidus yoghurt samples during production and storage (Fig. 1), The count of all starter cultures (S. thermophiles + Lb. bulgaricus + B.bifidum) in bifidus yoghurt increased during the fermentation and cold storage, S. thermophiles, it was 7.25, 7.35, $8.30,8.50,7.50,7.40$ and $6.60 \log _{10} \mathrm{cfu} / \mathrm{g}$, while $L b$. bulgaricus $7.35,7.65,8.40,8.25,7.60,7.55$ and $6.35 \log _{10} \mathrm{cfu} / \mathrm{g}$ and B. bifidum became $7.50,8.10$, $8.80,8.60,7.60,7,40$ and $6.60 \log _{10} \mathrm{cfu} / \mathrm{g}$ at zero time, $3,5,7,10,14$, and 21 days of storage, respectively.

Table (1): The mean values of titratable acidity (T.A \%) in prepared yoghurt samples during refrigerated storage (mean $\pm \mathrm{SD})$

\begin{tabular}{lll}
\hline $\begin{array}{l}\text { Samples } \\
\text { Storage days }\end{array}$ & TY & BY \\
\cline { 2 - 3 } Zero & $0.69 \pm 0.02$ & $0.67 \pm 0.02$ \\
3 & $0.71 \pm 0.02$ & $0.69 \pm 0.01$ \\
5 & $0.78 \pm 0.03$ & $0.75 \pm 0.03$ \\
7 & $0.80 \pm 0.02$ & $0.78 \pm 0.02$ \\
10 & $0.85 \pm 0.02$ & $0.82 \pm 0.03$ \\
14 & $1.25 \pm 0.13$ & $0.93 \pm 0.03$ \\
21 & $\mathrm{~S}$ & $1.16 \pm 0.03$ \\
\hline
\end{tabular}

TY: Traditional yoghurt BY: Bifidus yoghurt. S: Spoilage of sample by visualized mould growth 
Table (2): Viability of L. monocytogenes in the TY\&BY during their refrigerated storage (mean $\log _{10} \mathrm{cfu} / \mathrm{g} \pm$ $\mathrm{SD})$

\begin{tabular}{|c|c|c|c|c|c|c|c|}
\hline \multirow[t]{2}{*}{ Yoghurt sample } & \multicolumn{7}{|c|}{ Days of storage } \\
\hline & 0 & 3 & 5 & 7 & 10 & 14 & 21 \\
\hline TY & $7.00 \pm 0.26$ & $6.20 \pm 0.36$ & $5.80 \pm 0.17$ & $5.00 \pm 0.36$ & $3.13 \pm 0.31$ & $2.20 \pm 0.30$ & $\mathrm{~S}$ \\
\hline BY & $6.60 \pm 0.10$ & $5.40 \pm 0.03$ & $3.33 \pm 0.15$ & $1.47 \pm 0.25$ & $<1$ & & \\
\hline
\end{tabular}

TY: Traditional yoghurt $\quad$ BY: Bifidus yoghurt $\quad$ S: Spoilage of sample by visualized mould growth

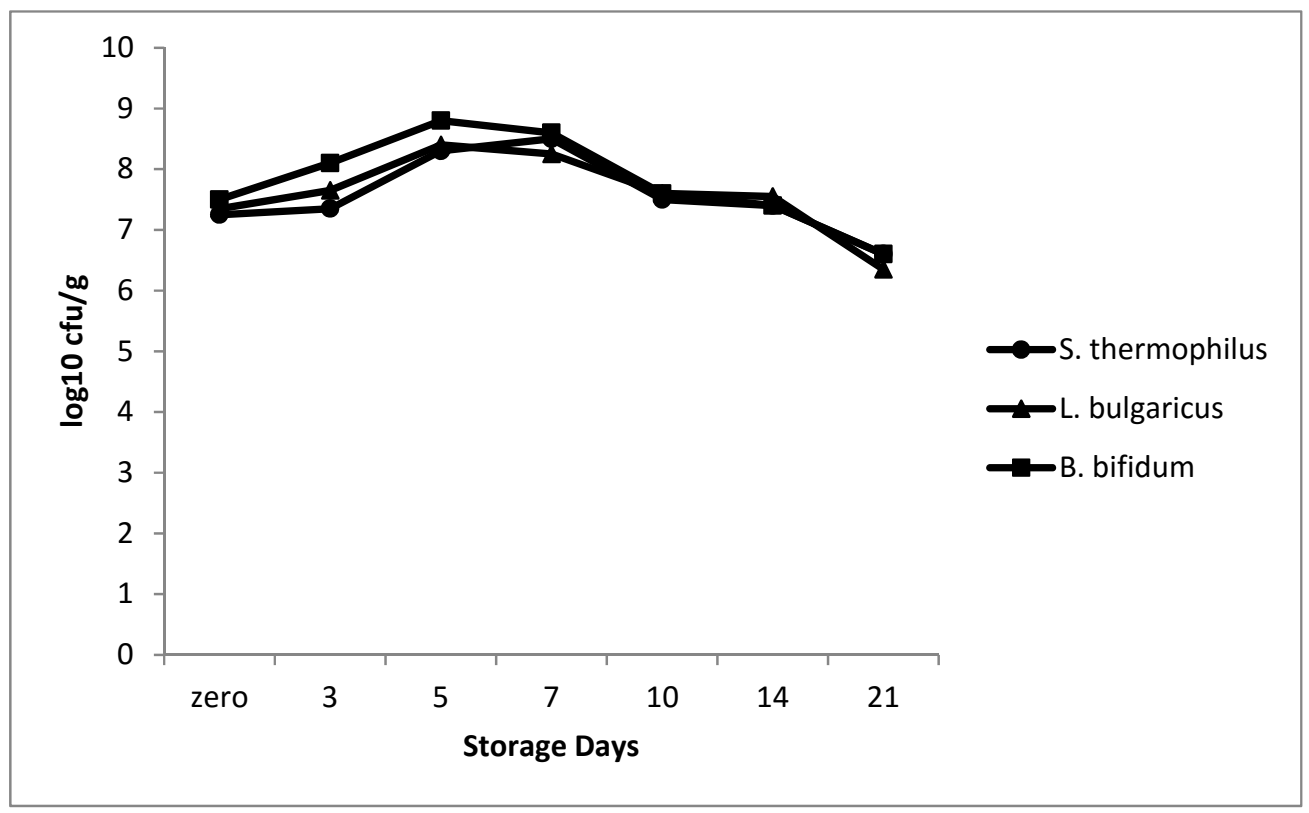

Fig. (1): The mean counts of S. thermophilus, Lb. bulgaricus and B.bifidum counts during production and storage of traditional and bifidus yoghurt.

\section{4- DISCUSSION}

Titratable acidity (TA) of yoghurt is 0.70 $0.80 \%$, the acid production in yoghurt depends on the growing of microorganisms and their ability for fermentation of the lactose in milk. Yoghurt is manufactured by addition of $S$. thermophilus and $L b$. bulgaricus. These organisms are active even at refrigerated temperatures and still can produce small amounts of lactic acid by fermentation of lactose resulting in noticeable TA increase (Shah et al., 1995). Table (1) represented the mean titratable acidity in TY \& BY, which increased over time from initial 0.69 and $0.67 \%$ at termination of fermentation (4h) to 1.25 and $0.93 \%$ by 14 days of storage at $4 \pm 1^{\circ} \mathrm{C}$ for $\mathrm{TY}$ and BY, respectively. The mean value of titratable acidity of all samples increased during storage period, but TY samples showed significantly higher values $(P<0.05)$ than BY samples.
The higher titratable acidity in TY samples than those in BY samples may be due to the amount of initial inoculum (3\%) of yoghurt starter culture (S. thermophilus and Lb. bulgaricus) compared to $(1.5 \%)$ in BY, in addition to the slow rate of bifidobacteria in the production of acidity (Dave and Shah, 1997). These results agreed with those obtained by Hussein and Kebary (1999) and AbdelAziz-Mona (2011) who found that bifidus yoghurt had lower acidity compared to traditional yoghurt. The acidification in yoghurt depends on the growing of microorganisms in the selection of starter culture and probiotic bacteria and their ability for lactic acid formation (RahnamaFatemeh et al., 2013). LAB is active even at refrigerated temperature and still can produce small amounts of lactic acid by fermentation of lactose resulting in noticeable TA increase (Shah et al., 1995).

Data presented in Table (2) showed the viability of the inoculated L. monocytogenes in the prepared 
yoghurt samples during production and cold storage $\left(4 \pm 1^{\circ} \mathrm{C}\right)$. The count of $L$. monocytogenes showed decreased in all yoghurt samples and its count became 3.3 and $5.00 \log _{10} \mathrm{cfu} / \mathrm{g}$ after 5 days of storage. Elimination of $L$. monocytogenes was observed on the $10^{\text {th }}$ day in BY samples, while still detected in TY till the day 14th of storage and became $2.20 \pm 0.31 \log _{10} \mathrm{cfu} / \mathrm{g}$. Similar results was obtained by Azizkhani and Toorya (2016) and Toorya (2016) who found that Bifidobacterium $\mathrm{Bb} 12$ showed inhibitory effect against $L$. monocytogenes in vitro, and (Rayes-Amnah, 2012) found that $\mathrm{LAB}$ inhibited the growth of $L$. monocytogenes in vitro.

From the above mentioned results which showed that bifidobacteria had an inhibitory effect against L. monocytogenes microorganism more than that of the yoghurt starter culture ( $S$. thermophilus and Lb. bulgaricus), that may be due to the antimicrobial agents produced by Bifidobacteria such as organic acids; mainly acetic acid and lactic acids (Bruno and Shah, 2002) and bacteriocins (Lengkey (Lengkey and Adriani, 2009).

The viability of probiotic bacteria in yoghurt must kept sufficiently high to ensure that consumers receive health benefits. These benefits include the prevention of diarrhea, balancing of intestinal microflora, stimulation of the immune system, antitumor properties and alleviation of lactose tolerance (El-Kholy et al., 2014; Guktepe, 2006). In order to produce these benefits. It is important to note that the number of lactic acid bacteria present in different systems of yoghurt was constant over time, as it kept in a range of 6 to 8 $\log _{10} \mathrm{cfu} / \mathrm{g}$, which is the need to exercise bactericidal action as well as being the recommended number by FAO/WHO (2010) as the amount of bacteria needed for exercising beneficial effects on the body (Dave and Shah, 1997; Gueimonde et al., 2004). The changes in the viable counts of $S$. thermophilus, Lb. bulgaricus and $B$. bifidum in yoghurt during production and storage are given in Fig. (2), it is clear that the $\log _{10} \mathrm{cfu} / \mathrm{g}$ of all yoghurt samples slightly increased till the $5^{\text {th }}$ and the $7^{\text {th }}$ days and then decreased slowly to the end of the storage period and reached 6.60, 6.35 and $6.60 \log _{10} \mathrm{cfu} / \mathrm{g}$. Over 21 days' storage at $4^{\circ} \mathrm{C}$ there was some decline in the numbers of bifidobacteria but the counts remained stable with values around 6-8 $\log _{10} \mathrm{cfu} / \mathrm{g}$. Similar observations were reported by Abdel-Aziz-Mona (2011) Abd El-Gawad et al. (2014); El-Kholy et al. (2014); Mani-López et al. (2014); Meg et al. (2013);
Ranasinghe and Perera (2016); Rayes-Amnah (2012) and Azizkhani and Toorya (2016)

Donkor et al. (2007) concluded that the ability of probiotic to survive in yoghurt was strain dependent, in addition Bifidobacteria could survive in yoghurt at sufficient levels $\left(>10^{6} \mathrm{cfu} / \mathrm{g}\right)$ for up to 28 days. Variation in the probiotic viability data among different authors may probably be attributed to strain variation, acid accumulation, interaction with starter cultures and storage condition.

\section{5- CONCLUSION}

The results demonstrated the capability of $B$. bifidum to inhibit the growth of L. monocytogenes, in vitro. Survival of $S$. thermophilus, $L b$. bulgaricus and $B$. bifidum in yoghurt were satisfactory as they remained viable at levels $>10^{7}$ $\mathrm{cfu} / \mathrm{g}$ after 21 days of storage at $4 \pm 1^{\circ} \mathrm{C}$, which indicate that the yoghurt would be a suitable vehicle for probiotic bacteria. Bifidobacteria has been shown to possess inhibitory activity toward the growth of L. monocytogenes during the fermentation and storage of yoghurt, as the presence of pathogenic bacteria as Staph. aureus pose a risk for public health. Therefore, the hygienic standard needs to be strengthened during manufacture and storage to ensure production of safe, high quality yoghurt.

\section{6- REFERENCES}

A.O.A.C., 2000. Dairy products. In: Official methods of analysis. Association of Official and Analytical Chemists, Inc., Gaitherburg, USA.

A.P.H.A. (American Public Health Association), 2001. Compendium of methods for the microbiological examination of foods. . $4^{\text {th }}$ Ed. Amer. Public Health Asso., Washington, D.C., USA.

Abd El-Gawad, I.A., El-Sayed, E.M., El- Zeini, H.M., Hafez, S.A., Saleh, F.A., 2014. Antibacterial activity of probiotic yoghurt and soy-yoghurt against Escherichia coli and Staphylococcus aureus. Nut. Food Sci. 4, 16.

Abdel-Aziz-Mona, M.M., 2011. The role of Bifidobacteria in improvement of physical, chemical and microbial quality of fermented dairy products. $\mathrm{PhD}$ Thesis. Benha Univ. Faculty of Vet. Med. 
Allerberger, F., Wagner, M., 2010. Listeriosis: a resurgent foodborne infection. Clin Microbiol Infect 16, 16-23.

Azizkhani, M., Toorya, F., 2016. Antimicrobial activities of probiotic yogurts flavored with peppermint, basil, and zataria against Escherichia coli and Listeria monocytogenes. J. of Food Quality and Hazards Control 3, 79-86.

Bachrouri, M., Quinto, E.J., Mora, M.T., 2002. Survival of Escherichia coli O157:H7 during storage of yoghurt at different temperatures. J. Food Sci 67, 1899-1903.

Bruno, F.A., Shah, N.P., 2002. Inhibition of pathogenic and putrefactive microorganisms by Bifidobacterium spp. Milchwiss 57, 617621.

Dave, R.L., Shah, N.P., 1997. Viability of yoghurt and probiotic bacteria in yoghurts made from commercial starter cultures. Int. Dairy J. 7, 33-41.

Donkor, O.N., Henriksson, A., Vasiljevic, T., Shah, N.P., 2007. Effect of acidification on the activity of probiotics in yoghurt during cold storage. Int Dairy J 16, 1181-1189.

El-Kholy, A.M., El-Shinawy;, Meshref, A.M.S., Korny, A.M., 2014. Screening of antagonistic activity of probiotic bacteria against food-borne pathogens. J. of App. \& Enviro. Microbiolo 2, 53-60.

FAO/WHO, 2010. Codex standard for fermented milks ( $2^{\text {nd }}$ ed.). Codex Stan 243-2003.

Gueimonde, M., Delgado, S., Mayo, B., RuasMadiedo, P., Margolles, A., Reyes-Gavilan, C.G., De, 1., 2004. Viability and diversity of probiotic Lactobacillus and Bifidobacterium populations included in commercial fermented milks. Food Res Int. 37, 839-850.

Guktepe, I., 2006. Probiotics as bio-preservatives for enhancing the food safety. In Goktepe, I., Juneja, V. K. and Ahmedna, M. ed., Probiotics in food safety and human health. CRC, Taylor and Fracis group 285-307.

Hull, R.R., Robert, A.V., 1984. Differential enumeration of Lactobacillus acidophilus in yoghurt. Journal Aust. Dairy technology 3, 160-164.

Hussein, S.A., Kebary, K.M.K., 1999. Improving viability of bifidobacteria by microentrapment and their effect on some pathogenic bacteria in stirred yogurt. Acta alimentaria 28, 113-131.

Kailasapathy, K., Harmstorf, I., Phillips, M., 2008. Survival of Lactobacillus acidophilus and Bifidobacterium animalis ssp. lactis in stirred fruit yogurts. Food Sci. Tech. 42, 1317-1322.

Kehagias, C., Koulouris, S., Arkoudelos, J.S., Samona, A., 2006. Viability and biochemical activity of Bifidobacteria in association with yoghurt starter cultures in Bifidus milk and bio-yoghurt during storage at $4^{\circ} \mathrm{C}$. Egyptian J. Dairy Sci. 34, 151-158.

Lengkey, H.A.W., Adriani, L., 2009. Effect of milk fermented with Lactobacillus acidophilus and Bifidobacterium spp. on lactic acid and acetic acid content on Staphylococcus aureus and Pseudomonas aeruginosa. Biotechnology in Animal Husbandry 25, 719-724.

Liu, D., 2006. Identification, subtyping and virulence determination of Listeria monocytogenes, an important foodborne pathogen. J Med Microbiol 55, 645-659.

Mani-López, E., Palou, E., López-malo, A., 2014. probiotic viability and storage stability of yogurts and fermented milks prepared with several mixtures of lactic acid bacteria. J. Dairy Sci. 97, 2578-2590.

Mattila-Sandholm, T., Myllariner, P., Crettenden, R., Mogensen, G., Fonden, R., Saarela, M., 2002. Technological challenges for future probiotic foods. Iternational Dairy J. 1-12.

McLauchlin, J., Mitchell, R.T., Smerdon, W.J., Jewell, K., 2004. Listeria monocytogenes and listeriosis: A review hazard characterization for use in microbiological risk assessment of foods. Int. J. of Food Microbiol. 92: , 15-33.

Meg, S.F., Adriano, G.C., Diana, M.D.A., José, d.A.F.F., Marcelo, C., Anderson, S.S., 2013. On the behavior of Listeria innocua and Lactobacillus acidophilus co-inoculated in a dairy dessert and the potential impacts on food safety and product's functionality. Food Control 34, 331-335.

Nighswonger, B.D., Brashears, M.M., Gilliland, S.E., 1996. Viability of Lactobacillus acidophilus and Lactobacillus casei in fermented milk products during refrigerated storage. J Dairy Sci 79, 212-219.

Ouwehand, A.G., Suomalainen, T., Tolkko, S., Salminen, S., 2002. In vitro adhesion of propionic acid bacteria to human intestinal mucus. Lait 82, 123-130.

Palacios, M.C., Haros, M., Rosell, M., Sanz, Y., 2008. Selection of Phytate-degrating human Bifidobacteria and application in whole wheat dough fermentation. J. Food Microbiolo. 25, 69-76. 
Rahnama-Fatemeh, Rezvan, P., Zahra, P.V., 2013. Production of probiotic soy-yogurt containing conjugated linoleic acid. Annals of Biological Research 4, 182-187.

Ranasinghe, J.G.S., Perera, W.T.R., 2016. Prevalence of Lactobacillus bulgaricus and Streptococcus thermophilus stability in commercially available yogurts in Sri lanka. Asian J. of Med. Sci. 7, 97-10.

Rayes-Amnah, A.H., 2012. Enhancement of probiotic bioactivity by some prebiotics to produce bio-fermented milk. Life Sci. J. 9, 2246-2253.

Shah, N.P., Lankaputhra, W.E.V., Britz, M.L., Kyle, W.S.A., 1995. Survival of Lactobacillus acidophilus and
Bifidobacterium bifidum in commercial yoghurt during refrigerated storage. Int Dairy J 5, 515-521.

Tharmaraj, N., Shah, N.P., 2003. Selective enumeration of Lactobacillus delbrueckii ssp. bulgaricus, Streptococcus thermophilus, Lactobacillus acidophilus, bifidobacteria, Lactobacillus casei, Lactobacillus rhamnosus, and propionibacteria. J Dairy Sci 86, 2288-2296.

Wu, X.L., Zhou, B.Y., Wu, L.J., Wu, Z.J., 2011. Effect of Bifidobacteria on respiratory and gastrointestinal tract in neonates receiving mechanical ventilation. Zonogguo Dang Dai Er Ke Za Zhi 13, 704-707. 